\title{
Caracterização das manifestações lingüísticas de uma família com Síndrome Perisylviana********
}

\author{
Characterization of the linguistic profile of a family with Perisylvian \\ Syndrome
}

\author{
Ecila Paula dos Mesquita de Oliveira* (ecilapaula@uol.com.br) \\ Marilisa Mantovani Guerreiro** \\ Catarina Abraão Guimarães**** \\ Iara Lêda Brandão-Almeida**** \\ Maria Augusta Montenegro***** \\ Fernando Cendes****** \\ Simone Rocha de Vasconcellos Hage*******
}

\section{*Fonoaudióloga. Mestranda em Neurologia pela Faculdade de Ciências Médicas da Universidade Estadual de Campinas (FCM- Unicamp).}

**Médica. Livre-Docente pela Unicamp. Professor Associado do Departamento de Neurologia da FCM-Unicamp

***Psicóloga. Mestre em Ciências Médicas pela FCM - Unicamp. Pós-Graduanda do Departamento de Neurologia da FCMUnicamp.

*****Médica. Mestre pela Universidade Federal de São Paulo (Unifesp). PósGraduanda do Departamento de Genética Médica da FCM-Unicamp.

******Médica. Professora Doutora de Neurologia Infantil do Departamento de Neurologia da Unicamp. Departamento de Neurologia da FCM-Unicamp.

*******Médico. Livre-Docente pela Unicamp. Professor Associado do Departamento de Neurologia da FCMUnicamp.

********Fonoaudióloga. Doutora em Ciências Médicas pela FCM - Unicamp. Professora Doutora do Departamento de Fonoaudiologia da Faculdade de Odontologia de Bauru da Universidade de São Paulo (FOB-USP).

*********Trabalho Realizado no

Departamento de Neurologia da FCM Unicampe no Departamento de Fonoaudiologia da FOB-USP.

Artigo de Relato de Caso

Artigo Submetido a Avaliação por Pares

Conflito de Interesse: não

Recebido em 11.02.2005 Revisado em 28.03.2005; 28.06.2005; 9.08.2005; 22.09 .2005 Aceito para Publicação em 22.09.2005.

\begin{abstract}
Background: perisylvian syndrome refers to a variety of clinical manifestations associated to lesions in the perisylvian or opercular regions. Polymicrogyria is the most common structural malformation found. The syndrome may be inherited and the clinical spectrum includes subtle language disturbances on one end and more severe characteristics such as prominent pseudobulbar signs and refractory epilepsy on the other end. Other studies have already associated perisylvian polymicrogyria with developmental language disorders or specific language impairment. Aim: to describe the language deficits of four members of a family with Perisylvian Syndrome, and to correlate these deficits to neuroimaging data Method: the patients underwent neuroimaging investigation, psychological assessment using the Weschler Intelligence Scales, and specific speech-language evaluation. The following tests were used for the assessment of vocabulary, phonology, syntax, pragmatics, reading and writing: Thematical Pictures of Yavas, ABFW - Child Language Test, Peabody Picture Vocabulary Test (PPVT), and other specific protocols. Results: magnetic resonance imaging revealed perisylvian polymicrogyria in all of the subjects, with varied locations and extensions. Speech-language assessment indicated significant oral and written language deficits in all of the subjects. Conclusion: the obtained data indicate that language impairment can co-exist with reading deficits in members of the same family. Neuroimaging findings reveal cortical alterations that are associated to specific language impairments within the spectrum of the Perisylvian Syndrome. Another important aspect evidenced by this study is the similarities in the language profiles of siblings and mother, suggesting that a variety of linguistic manifestations exist within the spectrum of the syndrome. Perisylvian polymicrogyria can be one of the neurobiological malformations involved in the manifestation of these deficits.
\end{abstract}

Key Words: Language Development Disorders; Learning Disorders; Nervous System Malformations.

\section{Resumo}

Tema: por Síndrome Perisylviana entende-se toda e qualquer manifestação clínica decorrente de lesão ou malformação que comprometa a região da fissura de Sylvius, sendo a polimicrogiria a alteração estrutural mais encontrada. A referida síndrome pode ser familiar, sendo que o espectro clínico pode variar desde manifestações leves de distúrbio de linguagem, até quadros extensos que cursam com proeminentes sinais pseudobulbares e epilepsia refratária. Estudos já correlacionaram a polimicrogiria perisylviana com a ocorrência do Distúrbio Específico de Linguagem. Objetivo: o objetivo desse trabalho foi descrever as alterações de linguagem em quatro membros de uma família com Síndrome Perisylviana, e relacioná-las a exames de neuroimagem. Método: os sujeitos foram submetidos a exames de ressonância magnética, à avaliação psicológica, por meio das Escalas Wechsler de Inteligência e à avaliação fonoaudiológica específica de linguagem. Para avaliação do vocabulário, fonologia, sintaxe, pragmática, leitura e escrita foram utilizados testes como: as Figuras temáticas do Yavas, o ABFW - Teste de Linguagem Infantil, o Peabody Picture Vocabulary Test (PPVT), além de outros protocolos específicos. Resultados: os exames de ressonância magnética evidenciaram polimicrogiria perisylviana de localização e extensão variáveis em todos os sujeitos. A avaliação fonoaudiológica também demonstrou alterações de linguagem oral e escrita significativas em todos os sujeitos. Conclusão: os nossos dados mostraram que distúrbios de linguagem podem co-ocorrer com alterações de leitura em membros da mesma família. A constatação de alterações corticais evidencia a presença de distúrbios específicos da linguagem no espectro da síndrome perisylviana. Outro aspecto importante evidenciado nesse estudo é a semelhança do perfil de linguagem entre os irmãos e a mãe, sugerindo que seja possível a existência de uma variedade de manifestações lingüísticas dentro do espectro da referida síndrome, podendo ser a polimicrogiria perisylviana um dos substratos neurobiológicos destes distúrbios.

Palavras-Chave: Transtornos do Desenvolvimento da Linguagem; Transtornos de Aprendizagem; Malformações do Sistema Nervoso. 


\section{Introduction}

Language is a complex process involving participation and interaction of all its components: phonology, semantic, morphology, syntax and pragmatics. Any impairment of one or more components will affect general language development. Acquisition and organization of these components are related to human being internal capabilities as well as to its environment, which shall be rich in stimuli and allow several language experiences (Scheuer et al., 2003).

Environment influence is evidenced by the quantity and quality of language models received by the child, generating language development. Therefore, affective feature of relations between child and environment, mainly at home, are fundamental to assure conditions to use communication as a prime inter-personal relationship medium (Befi-Lopes et al., 2001).

Language acquisition also depends on biological factors, such as central nervous system integrity and maturity. Brain language-related functions are mainly located and brain cortex. Language processing in the brain involves primary hearing cortex, responsible for initial hearing processing; parietal-temporal cortex responsible for phonological coding; frontal antero-inferior cortex responsible for semantic association; premotor area, next to Sylvius fissure, responsible both for articulation coding and oral language motor programming and inferior motor cortex involved with oral language execution (Grigorenko, 2001).

Considering possibility of brain malfunction involving children with language impairments, it is important to know normal cortical formation process. Normal brain cortical formation involves three basic steps: neuronal proliferation and differentiation, neuronal migration and cortical organization, the final step that will create 6 cortical layers. Any disorder during one or more steps will provoke macro or microscopic changes on cortical architecture and/or relations between brain cortex and sub-cortical white substance, such as: esquizencephalia, lisencephalia, pachigyria, microgyria, agyria, among others. Since brain cortex formation disorders occur during embryonic period, it could be suspected that harmful interferences to embryo present determining aspects to this abnormalities etiology.

With neuroimaging techniques advancement, it is possible to view cortical malformations, as well their relations to language impairments. Polymicrogyria is among the most frequent structural impairments found; this is a cortical development malformation provoked by a defect during cortical organization phase, featured by multiple small turns. Polymicrogyria can vary in extent, degree and location in brain cortex.

Polymicrogyric cortex location in Sylvius fissure region together with some clinical manifestations, features Perisylvian Syndrome. Pseudobulbar signs, language impairments, epilepsy and motor handicap usually feature its clinical problem and when it is congenital it can be frequently already evidenced during birth, with sucking, swallowing and feeding difficulty. Sucking baby can easily choke and sialorrhea is an important sign that can follow patients during its whole life (Guerreiro et al., 2000).

It is know that Perisylvian Syndrome clinical spectrum can range from language impairment slight manifestations, with no other change during neurological examination, to extensive problems with pseudobulbar signs and refractory epilepsy, depending on polymicrogyria extent on perisylvian region. Other less frequent clinical manifestations can also follow Perisylvian Syndrome, such as slight development retardation, hypotonia, arthrogriposis, tetraparesis, hemiparesis, paraparesis, micrognathia, nauseous reflex absence, deformed feet, syndactilism and dysplastic hip (Guerreiro et al., 2000).

Some important studies have already correlated perisylvian polymicrogyria to Language Specific Disorder (LSD) - (Hage and Guerreiro, 2001; Montenegro et al., 2001; Guerreiro et al., 2002; Brandão-Almeida et al., 2003), but this cortical development can also be followed by language manifestations that do not necessarily evidence a language specific language disorder.

LSD diagnosis is suggested when child presents language impairments, which cannot be attributed to hearing handicap, brain paralysis, mental handicap, development invading disorders, psychotic disorders, acquired brain injuries and environment (Hage and Guerreiro, 2001; Befi-Lopes et al., 2002).

Manifestation found are: phonological simplifications, restricted vocabulary, simplified and little varied grammar structuring and words ordering in an unusual form. When comprehension 
is impaired, difficulties to understand sentences or specific words, such as space and temporal markers, can be remarked besides performance of language commands in an incorrect manner (Hage e Guerreiro, 2004). According to Befi-Lopes (2004) LSD is featured in children that do not present factors that could impair or delay language development process and do not develop it as expected, presenting when they are 5 or 6 years old, atypical development pattern and maintaining language significant difficulties along their life.

Among language impairments found in subjects presenting perisylvian polymicrogyria, some can be evidenced, depending on cortical injury extent and location (Hage e Guerreiro, 2004).

Familiar nature of referred disorder is being largely studied and in most cases, confirmed, when after language assessment and neuroimaging examinations language residual deficits are found in a large number of children with LSD and in their parents.

During recent family aggregation studies, Flax et al. (2003) pointed out a co-existence of oral language and reading disorders in children with LSD and members of their families. Study results showed that language and reading impairments for nuclear members of probing group was significantly higher compared to control groups members and that $68 \%$ of children with LSD of one family aggregation also presented reading impairment. Based on results, authors concluded that when language impairments occur in the family of subjects affected by LSD, these disorders co-exist with reading disorders.

From the same studies perspective concerning relations between learning problems and oral language impairments, Capellini and Oliveira (2003) stated that both for reading specific impairment (dyslexia) and learning impairment, language development impairments are often found, both in a single component, such as phonological one, and in several components (phonological, syntactic, semantic and pragmatic). Phonological system impairment, in both situations, will affect grapheme-phoneme conversion for activities relating to oral and written reading, according to the authors. Ávila (2004) in a chapter concerning phonological awareness issues, also pointed out relations between language development impairments and reading and writing difficulties: children presenting language acquisition delay can develop phonological disorders, which can lead to phonological awareness difficulties development and consequently to learning and reading difficulties.
Lately, genes role in LSD etiology have been also focused. Before molecular genetics progress, it is necessary to better understand which LSD aspects are hereditary. For this, studies with twins are carried out to allow distinction between genetic factors and environmental influences. Both for oral problems and written language, there are inherited risk factors and factors related to social environment (Ávila, 2004). LSD can be inherited due to neurological-anatomic impairments found in children's parents presenting such disorder.

Bishop (2002) reports that although LSD often appears in families, most of affected people do not consistently present a single defective gene. Lai et al. (2001) described how a small genetic mutation leads to a severe speech and language disorder, in approximately half of a British family's members, the KE family. O’Brien et al. (2003) carried out a genetic investigation in 96 subjects presenting LSD, and a mutation was pointed out in gene FOXP2 locate in chromosome 7q 31. Nevertheless, the more LSD genetics is studied, the more evidence that there are probably many different genes whose changes could lead to language impairments is stronger. Perisylvian Syndrome family form seems to hold genetic heterogeneity (Brandão-Almeida et al., 2003).

Before this, the purpose of this study is to describe language manifestations in a family with Perisylvian Syndrome, relating these data to neuroimaging examination.

\section{Method}

Present study was submitted and approved by the Ethics Committee of Unicamp Medical Sciences Faculty - Ethics Council on Research (CEP), number 382/2003, according to resolution 196/96 of CEP (BRAZIL. Resolution MS/CNS/CNEP no. 196/96 of October 10th 1996). Family subjects have signed consent term informed.

Amongst families assisted at the Clinic of Neurological-Psychological-Language in childhood of Hospital de Clínicas of Universidade Estadual de Campinas (Unicamp), one has been selected to achieve study purpose. Four subjects, three male and one female, being 8, 15, 19 and 40 years old respectively, constitute this family.

Criterion for the selection of families with Perisylvian Syndrome at the clinic mentioned above is that at least one family subject shall present clinical diagnosis of the syndrome congruent with neuroimaging examination; other subjects can present only syndrome characteristic clinical signs, 
independently of image. To better feature this study, a family in which all subjects presented perisylvian polymicrogyria in neuroimaging examination, as show in heredogram below, besides syndrome clinical manifestations, especially language ones was selected.

Study subjects were submitted to: clinical neurological assessment: neuroimaging examination though MR - 3D, neurologicalpsychological assessment and phonological assessment.

In clinical neurological assessment aspects were evidenced referring to: pregnancy, delivery and possible intercurrences between these two events, neurological-psychomotor development, speech development, pseudobulbar signs presence, epileptic crisis and data concerning family history.

For psychological assessment, an area professional applied tests suitable for the age group. Tests applied included WECHSLER: WPPSI - WISC-III- WECHSLER Intelligence Scale for Children $-3^{\text {rd }}$ edition for children being more than 6 years old and WAIS - R for adults (Weschsler, 2002).

For phonological assessment participating subjects have been assessed in areas referring to: vocabulary, phonology, syntax and pragmatics, through tests and protocol involving spontaneous language sample.

\section{For Oral Language Assessment:}

- Yavas Thematic Pictures (Yavas et al., 1992) for phonological production assessment;

- Peabody Picture Vocabulary Test (PPVT) - revised, Hispanic-American adaptation (Dunn e Dunn, 1986), for receptive-hearing vocabulary assessment. Since this test does not comprise $\mathrm{S} 1$ age group, its vocabulary was assessed through sample; - articulating and buccofacial Praxyas, through Hage's protocol (2003). - protocol per language sample for morpho-syntax and pragmatics assessment, described in Hage and Guerreiro (2001). Criteria for morpho- syntax were: number of predominant nuclei in sentence syntactic organization, omissions type, nominal and verbal inflection. As to pragmatic skill, two aspects were considered: conversation skills (simple and expansive turns, coherent and incoherent, turns predominance to start or answer the conversation) and communicative functions (instrumental, heuristic, nomination, protest, informative, interactive and narrative).

For written language assessment:

- phonological Awareness Test (Capovilla and Capovilla, 2003);

. TDE - School Performance Test (Stein, 1994) to assess school performance and its compatibility with chronological age, for children with up to 6th degree level.

FIGURE 1. Heredogram of family studied.

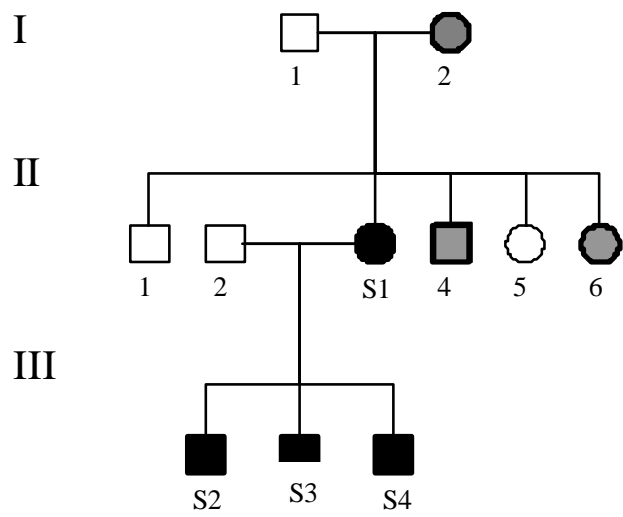

Caption: numbers I, II and III indicate the generation the individual belongs to; symbols in black indicate patients with clinical signs and neuroimaging compatible with perisylvian PMG examined by the author; symbols in gray indicate patients with clinical signs and neuroimaging confirming perisylvian PMG that were not examined by the author.

II - S1 - PMG PS parietal posterior bilateral

III - S2 - PMG PS diffused bilateral

III - S3 - PMG PS parietal posterior bilateral

III - S4 - PMG PS parietal posterior bilateral

I-2 PMG PS diffused bilateral

II-4 PMG PS frontal bilateral

II-6 PMG PS parietal posterior bilateral 
Written language sample of subjects with education level higher than the $6^{\text {th }}$ degree was obtained through dictation, text elaboration and reading request, both narratives. For this, texts with different complexity degrees were selected and used according to education level. Analysis criteria were: spelling and basic stressing rules mastering/ dictation punctuation in dictation; spelling and basic stressing rules mastering/ dictation punctuation, coherence and cohesion in spontaneous text; grapheme/phoneme conversion and understanding skills in reading. It should be pointed out that written sample analysis has taken into account subject's education level and the way it uses writing and reading.

\section{Results}

TABLE 1. Clinical and neuroimaging features of studied family.

\begin{tabular}{c|ccc|c} 
Sujeitos & $\begin{array}{c}\text { Sinais } \\
\text { Pseudo- } \\
\text { bulbares }\end{array}$ & Epilepsia & $\begin{array}{c}\text { Exame } \\
\text { Neurológico }\end{array}$ & RM \\
S1 & - & - & Normal & $\begin{array}{c}\text { PMG Per Bilateral } \\
\text { Posterior com } \\
\text { predomínio à D }\end{array}$ \\
S2 & + & - & Normal & $\begin{array}{c}\text { PMG Per Bilateral } \\
\text { Difusa }\end{array}$ \\
S3 & - & - & Normal & $\begin{array}{c}\text { PMG Per Bilateral } \\
\text { Posterior }\end{array}$ \\
S4 & - & - & Normal & $\begin{array}{c}\text { PMG Per Bilateral } \\
\text { Posterior }\end{array}$ \\
\hline
\end{tabular}

Legenda: + : presente; -: ausente; RM = ressonância magnética de crânio; PMG = polimicrogiria; Per = perisylviana; $\mathrm{D}=$ direita.

TABLE 2. Psychological assessment results description.

\begin{tabular}{cc|c|c} 
Sujeitos & QI Total & QI Verbal & QI Execução \\
S1 & 85 & 80 & 93 \\
S2 & $62-$ ID & $57-$ ID & 74 - limítrofe \\
S3 & 95 & 97 & 95 \\
S4 & 94 & 93 & 97 \\
\hline
\end{tabular}

Legenda: QI: quociente de inteligência; ID: intelectualmente deficiente.

TABLE 3. Oral language data description.

\begin{tabular}{cccccc} 
Sujeitos & $\begin{array}{c}\text { Produção } \\
\text { Fonológica }\end{array}$ & $\begin{array}{c}\text { Vocabulário } \\
\text { Receptivo }\end{array}$ & Sintaxe & Pragmática & $\begin{array}{c}\text { Praxias } \\
\text { Articulatórias } \\
\text { e Buco-Faciais }\end{array}$ \\
\hline S1 & sem alterações & sem alterações & sem alterações \\
$(40$ anos $)$ & $\begin{array}{c}\text { com alterações } \\
\text { distúrbio fonológico } \\
\text { com produções } \\
\text { desviantes }\end{array}$ & $\begin{array}{c}\text { baixo inferior } \\
\text { PPVT }-66\end{array}$ & $\begin{array}{c}\text { sem alterações } \\
\text { omissão de núcleos }\end{array}$ & $\begin{array}{c}\text { com alterações } \\
\text { habilidades conversacionais e } \\
\text { funcionais restritas }\end{array}$ & dispraxia \\
$(19$ anos $)$ & sem alterações & médio alto & sem alterações & sem alterações & sem alterações \\
S3 & PPVT - 107 & sem alterações & sem alterações
\end{tabular}

Legenda: PPVT - Peabody Picture Vocabulary Test. 
TABLE 4. Written language data description

\begin{tabular}{|c|c|c|c|c|}
\hline Sujeitos & $\begin{array}{c}\text { Prova de Consciência } \\
\text { Fonológica }\end{array}$ & Leitura & Escrita & Aritmética \\
\hline $\begin{array}{c}\text { S1 } \\
(40 \text { anos })\end{array}$ & $\begin{array}{c}\text { SiS: } 4 / 4 \\
\text { SiF: } 2 / 4 \\
\text { R: } 1 / 4 \\
\text { A: } 3 / 4 \\
\text { SeS: } 4 / 4 \\
\text { SeF: } 2 / 4 \\
\text { MS: } 2 / 4 \\
\text { MF: } 2 / 4 \\
\text { TS: } 4 / 4 \\
\text { TF: } 0 / 4\end{array}$ & $\begin{array}{l}\text { dificuldades } \\
\text { (amostra) }\end{array}$ & $\begin{array}{c}\text { dificuldades } \\
\text { significativas } \\
\text { (amostra) }\end{array}$ & $\begin{array}{l}\text { dificuldades significativas } \\
\text { (Amostra) }\end{array}$ \\
\hline $\begin{array}{c}\text { S2 } \\
\text { (19 anos) }\end{array}$ & $\begin{array}{c}\text { SiS: } 4 / 4 \\
\text { SiF: } 0 / 4 \\
\text { R: } 1 / 4 \\
\text { A: } 2 / 4 \\
\text { SeS: } 4 / 4 \\
\text { SeF: } 4 / 4 \\
\text { MS: } 2 / 4 \\
\text { MF: } 3 / 4 \\
\text { TS: } 0 / 4 \\
\text { TF: } 1 / 4\end{array}$ & $\begin{array}{l}\text { dificuldades significativas } \\
\text { (amostra) }\end{array}$ & $\begin{array}{l}\text { dificuldades } \\
\text { significativas } \\
\text { (amostra) }\end{array}$ & $\begin{array}{l}\text { dificuldades } \\
\text { significativas } \\
\text { (amostra) }\end{array}$ \\
\hline $\begin{array}{c}\mathrm{S} 3 \\
(15 \text { anos })\end{array}$ & $\begin{array}{c}\text { SiS: } 4 / 4 \\
\text { SiF: } 3 / 4 \\
\text { R: } 3 / 4 \\
\text { A: } 4 / 4 \\
\text { SeS: } 4 / 4 \\
\text { SeF: } 4 / 4 \\
\text { MS: } 4 / 4 \\
\text { MF: } 4 / 4 \\
\text { TS: } 4 / 4 \\
\text { TF: } 0 / 4\end{array}$ & $\begin{array}{c}\text { sem } \\
\text { dificuldades } \\
\text { (amostra) }\end{array}$ & $\begin{array}{l}\text { dificuldades } \\
\text { (amostra) }\end{array}$ & $\begin{array}{l}\text { dificuldades } \\
\text { (amostra) }\end{array}$ \\
\hline $\begin{array}{c}\text { S4 } \\
(8 \text { anos })\end{array}$ & $\begin{array}{c}\text { SiS: } 4 / 4 \\
\text { SiF: } 1 / 4 \\
\text { R: } 2 / 4 \\
\text { A: } 2 / 4 \\
\text { SeS: } 4 / 4 \\
\text { SeF: } 2 / 4 \\
\text { MS: } 4 / 4 \\
\text { MF: } 2 / 4 \\
\text { TS: } 4 / 4 \\
\text { TF: } 0 / 4\end{array}$ & $\begin{array}{l}\text { rendimento inferior } \\
\text { (TDE) }\end{array}$ & $\begin{array}{l}\text { rendimento inferior } \\
\text { (TDE) }\end{array}$ & $\begin{array}{l}\text { rendimento inferior } \\
\text { (TDE) }\end{array}$ \\
\hline
\end{tabular}

Legenda: TDE - Teste de Desempenho escolar; SiS: síntese silábica; SiF: síntese fonêmica; R: rima; A: aliteração; SeS: segmentação silábica; SeF: segmentação fonêmica; MS: manipulação silábica; MF: manipulação fonêmica; TS: transposição silábica; TF: transposição fonêmica. 


\section{Discussion}

Considering main study purpose of describing language manifestations in members of a family presenting Perisylvian Syndrome and relate them to neuroimaging examinations, some major aspects will be pointed out.

Table 1 describes clinical neurological assessment and neuroimaging results of 4 subjects of family studied. Our results showed that pseudobulbar signs could be found only in one subject, despite the fact that they all present cortical impairments during magnetic resonance. Pseudobulbar signs shall be understood as sucking, masticating and swallowing difficulties and sialorrhea during the first childhood, as well as blowing tongue moving (protrusion and raising/ lowering motions) and voluntary facial motion dissociation difficulties during clinical neurological examination. As reported in the introduction, Perisylvian Syndrome involves variable degrees of pseudobulbar signs, facial diplegia, speech and/ or language impairments, tongue protrusion and epilepsy. During a study with 12 children (Gropman et al., 1997), presenting perisylvian polymicrogyria, 7 of them $(50 \%)$ presented epilepsy, varying in time, frequency and fit type. The fact that this study was carried out in epilepsy centers can justify high frequency of this manifestation. With new studies in different populations, it can be remarked that epilepsy is not an obligatory condition of this syndrome and when present is generally easily controlled (Guerreiro et al., 2000).

As to neuroimaging perisylvian polymicrogyria could be noticed with variable extent and location, in the 4 subjects. Amongst the 3 brothers (S2, S3, S4), two presented parietal posterior bilateral perisylvian polymicrogyria (S3 e S4). Montenegro et al. (2001) remarked that from a series of 17 subjects affected by perisylvian syndrome, 7 presented polymicrogyria restrained to sylvius fissure parietal area and showed a slight condition of speech an/or language impairment, while the other 10 presented diffused impairment around sylvius fissure and developed pseudobulbar impairments and even epilepsy. This diffused impairment was found in S2, which presented, during neuroimaging examination a bilateral diffused perisylvian polymicrogyria condition. Guerreiro et al. (2002) also remarked that children presenting diffused polymicrogyria around sylvius fissure had much more severe LSD, while children with polymicrogyria limited to parietal area presented little or no language impairment. The sole family adult subject (S1) presented a discrete bilateral perisylvian polymicrogyria, predominantly on the right in the posterior region of sylvius fissure.

In our study, $\mathrm{S} 2$ is the most affected not only in oral and written language impairment, but also in cognitive aspect and pseudobulbar sign. Corroborating literature findings (Brandão-Almeida et al., 2003; Guerreiro et al., 2002; Hage and Guerreiro, 2001; Guerreiro et al., 2000), this subject image is the most extensive image among the other three family members. On the other hand, S3 and $\mathrm{S} 4$ presented a less extensive image, a slighter form of perisylvian syndrome. It should be pointed out that patients with polymicrogyria only on posterior parietal regions present more often, a family history of perisylvian syndrome or language delay (Brandão-Almeida et al., 2003), this aspect is confirmed by 3 subjects of the family studied (S1, S3, S4)

Table 2 describes psychological assessment results of 4 family subjects. It is known that intelligence testes application for children with LSD associated to Perisylvian Syndrome indicates a discrepancy between language and non-language skills (Hage and Guerreiro, 2001; Guerreiro et al., 2002). In a study formerly carried out by the authors, subjects' execution intellectual quotient (IQ) ranged within a ranking group far better than verbal IQ. Some subjects presented a non-verbal skills IQ within borderline group. One of the hypotheses to explain such findings would be that tests aiming at non-verbal capabilities assessment, could somehow involve language processes, which impair results obtained. Therefore, subjects with LSD may present a series of non-verbal disorders, such as difficulty concerning symbolic game development, hyperactivity, attention deficit and some cognitive impairment (Hage and Guerreiro, 2004). In our study, S1 and S4 confirm a better execution IQ compared to verbal IQ. Despite S2 presented low IQ values, not within LSD spectrum, discrepancy between verbal and execution quotient was also remarked.

Tables 3 and 4 describe results of phonological assessment, which as described in methodology, involved oral and written language aspects. It should be pointed out that despite the fact that subjects $\mathrm{S} 1, \mathrm{~S} 3$ and $\mathrm{S} 4$ did not present a phonological disorder as subject S2, they present a similar history of language delay, starting orality around 3, 4 years old. Amongst the 4 subjects of 
family studied, S3 and S4 presented a similar language condition: no impairment in oral language, but reading and writing difficulties. In these activities $\mathrm{S} 4$ that was attending the $2{ }^{\text {nd }}$ degree of elementary school at a public school when assessment was carried out, presented the worst outcome, compared to his brother S3, attending the 1 st degree of high school, also at a public school.

According to Ávila (2004), children with persisting language acquisition delay also present the risk of developing phonological deviations and children with phonological awareness difficulties also present risks of reading and writing learning difficulties. Thus, children that still present language problems when they arrive to reading and writing learning step are candidates to writing impairments (Godoy, 2003).

Nevertheless, there are some cases where despite not showing language impairments, the child in school age presents difficulties to learn alphabet principle and also difficulties to master written code at spelling level, what can be evidenced by the language manifestations presented by the brothers S3 e S4, reading and writing activities impairments presented by these subjects are significant, as according to dyslexia international associations, language development delay or difficult to learn new words are pointed out as possible risk factors for reading and writing disorder development (Ávila, 2004).

In $\mathrm{S} 4$ assessment it can be remarked that major difficulties are concentrated on items constituting phonological awareness test. Considering aspects discussed in the introduction, the relation between phonological awareness and reading and writing learning is important and shall be taken into account, as children in pre-school age and presenting poor phonological awareness capabilities will have difficulties to learn alphabet principle and recognize words. Furthermore, phonological awareness is also affected by the experience type the child can have: as they have little contact with written culture, it is common for children belonging to less culturally and socially favored classes, to present less language reflection opportunities (Freitas, 2003).

S2 phonology assessment results show impairment for all aspects assessed. Extent and seriousness of clinical condition clearly show a correlation between language impairment and reading and writing impairment, as reported in the literature on polymicrogyria extensive cases. Besides brain impairment, psychological assessment results also contributed to the low language assessment outcome.

The only adult assessed (S1), mother of the three other members of the family, presented impairments concerning reading and writing activities. Despite having incomplete high school degree and not using reading and writing daily, S1 difficulties were not significant (cohesion errors, voiceless/sonorous exchange and many spelling errors) and cannot be justified only by the lack of school opportunity.

As to correlation of language assessment and neuroimaging findings, S2 language profile is clearly justified by the brain impairment extent together with his cognitive deficit. Some subjects present a normal image examination and slight clinical manifestations, suggesting that very subtle impairment cannot be detected by current neuroimaging technology yet. The contrary can also be true, as many children with no language impairment can present brain atypical features (BefiLopes, 2004). Thus, such atypical features can be considered as risk factors for disorder development, but it nature, seriousness and persistence can be probably affected by non-biological factors, such as environment stimulation and social-cultural interactions. Besides this, the fact that one subjects of this family presented brain impairments with no evident clinical manifestations, can be explained by the fact that brain is a functional system, that is, its functioning results from the coordinated activity of many different modules and each one employs its own processing form, independently of the other ones activity.

We know that most complex processes, such as speech production and language processing result from many brain interactions, that is, there is no simple manner of relating the function of a destroyed brain tissue fragment to the lack of skill that patient could present due to the injury. Therefore, knowledge acquired about the role of certain brain regions, based on brain injuries effects is extremely valuable, but it is still experimental and is much more useful combined with brain functions knowledge obtained by other means (Shaywitz et al., 2001). 


\section{Conclusion}

Study checked language disorders presence co-existing with reading and/or writing impairments in members of the same family, as stated by researches concerning this matter, mentioned in the study introduction. Presence of language impairments in families, associated to cortical development impairment finding through neuroimaging, brings important information as to complex relations between brain and mental functions and also indicates the possibility of language specific impairments conditions being a part of perisylvian syndrome spectrum.

Through the purpose set in the beginning of the study, the relation between relatives language manifestations and neuroimaging examinations,

\section{References}

AVILA, C. R. B. Consciência fonológica. In: FERREIRA, L. P.; BEFI-LOPES, D. M.; LIMONGI, S. C. O. (Eds.). Tratado de Fonoaudiologia. São Paulo: Roca, 2004.

BEFI-LOPES, D. M. Avaliação, diagnóstico e aspectos terapêuticos nos distúrbios específicos de linguagem. In: FERREIRA, L. P.; BEFI-LOPES, D. M.; LIMONGI, S. C. O. (Eds.). Tratado de Fonoaudiologia. São Paulo: Roca, 2004.

BEFI-LOPES, D. M.; ARAUJO, K. de.; GIUSTI, E. Diagnóstico diferencial nas alterações de desenvolvimento da linguagem: contribuição de uma análise comparativa. $J$. Bras. Fonoaudiologia, Curitiba, v. 3, n. 12, p. 204-211, jul.-set. 2002.

BEFI-LOPES, D. M.; MORSELLI, A. A.; ARAÚJO, K. Intervenção fonoaudiológica em gêmeos com alteração de linguagem: relato de caso. J. Bras. Fonoaudiologia, Curitiba, v. 2, n. 7, p. 116-125, abr.-jun. 2001.

BISHOP, D. V. M. The role of genes in the etiology of specific language impairment. Journal of Communication Disorders, n. 35, p. 311-328, 2002. was useful to confirm that subjects' images evidencing extensive cortical involvement would present more severe clinical manifestations, while subjects' images evidencing posterior and/or focal cortical impairment would present more subtle clinical manifestations; it also confirmed some authors' reports stating that subjects presenting polymicrogyria only on posterior parietal regions would more often present a family history of Perisylvian Syndrome and speech delay. Finally, it is pointed out that magnetic resonance examination carried out with criterion and addressed to a diagnostic hypothesis before a child presenting language acquisition and development delay associated to oral-motor malfunction and/or pseudobulbar signs, is well indicated.

BRANDÃO-ALMEIDA, I. L. HAGE, S. R. V.; GUIMARÃES, C. A.; SANTOS, N. F.; OLIVEIRA, E. P. M.; MONTENEGRO, M. A.; TORRES, F. R.; SECOLIN, R. MIN, L. L.; CENDES, F.; LOPES-CENDES, I.; GUERREIRO, M. M. Clinical features and MRI findings associated with familial congenital bilateral perisylvian syndrome. Epilepsia Journal of the International League Against Epilepsy, v. 44, suppl. 8, p. 90, 2003.

CAPELlini, A. S.; OLIVEIRA, K. T. Problemas de aprendizagem relacionados às alterações de linguagem. In: CIASCA, S. M. Distúrbio de aprendizagem: proposta de avaliação interdisciplinar. São Paulo: Casa do Psicólogo, 2003. p. 113-139.

CAPOVIlla, A. G. S.; CAPOVILla, F. C. Prova de consciência fonológica. In: CAPOVILLA, A. G. S.; CAPOVILlA, F. C. Problemas de leitura e escrita. São Paulo: Memnon, 2003.

DUNN, L. M.; DUNN, L. M. Peabody picture vocabulary test-revised. Circle Pines, MN: American Guidance Service, 1986. 
FLAX, J. F.; REALPE-BONILLA, T.; HIRSCH, L. S.; BRZUSTOWICZ, L. M.; BARTLETT, C. W.; TALLAL, P. Specific language impairment in families: evidence for co-occurrence with reading impairments. Journal of Speech, Language and Hearing Research, v. 46, p. 530-543, june. 2003.

FREITAS, G. C. M.; SANTOS, R. M. Desvios fonológicos na fala e na escrita: uma relação previsível? Fono Atual, v. 6 , n. 23 , p. 26-32, jan.-mar. 2003.

GODOY, D. M. A. O papel da consciência fonológica no processo de alfabetização. Pró-Fono Revista de Atualização Científica, v. 15, n. 3, p. 241-250, 2003.

GRIGORENKO, E. L. Developmental dyslexia: na update of genes, brains and environments. J. Child. Psychol. Psychiatry, v. 42, n. 1, p. 91-125, 2001.

GROPMAN, A. L.; BARKOVICH, A. J.; VEZINA, L. G.; CONRY, J. A.; DUBOVSKY, E. C.; PACKER, R. J. Pediatric congenital bilateral perisylvian syndrome: clinical and MRI features en 12 patients. Neuropediatrics, v. 1, n. 28, p. 198-203, 1997.

GUERREIRO, M. M.; ANDERMANN, E; GUERRINI, R.; DOBYNS, W. B.; KUZNIECKY, R.; SILVER, K.; VANBOGAERT, P.; GILLAIN, C.; DAVID, P.; AMBROSETTO, G.; ROSATI, A.; BARTOLOMEI, F.; PARMEGGIANI, A.; PAETAU, R.; SALONEN, O.; IGNATIUS, J.; BORGATTI, R.; ZUCCA, C; BASTOS, A. C.; PALMINI, A.; FERNANDES, W.; MONTENEGRO, M. A.; CENDES, F.; ANDERMANN, F. Familial perisylvian polymicrogyria: a new familial syndrome of cortical maldevelopmental. Annals of Neurology, v. 48, p. 39-48, 2000.

GUERREIRO, M. M.; HAGE, S. R. V.; GUIMARÃES, C. A.; VENTURINI, D. A.; FERNANDES, W.; SEVERINO, P.; PIOVESANA, A. M. S. G.; MONTENEGRO, M. A.; CENDES, F. Polymicrogyria as a major cause of developmental language disorder. Neurology, v. 59, n. 2, p. 245-250, 2002

HAGE, S. R. V. A avaliação fonoaudiológica em crianças sem oralidade. Tópicos em Fonoaudiologia. Rio de Janeiro: Revinter, 2003. v. 5, p. 175-185
HAGE, S. R. V.; GUERREIRO, M. M. Distúrbio específico do desenvolvimento da linguagem: subtipos e correlações neuroanatômicas. Pró-Fono Revista de Atualização Científica, v. 13, n. 2, p. 233-241, 2001.

HAGE, S. R. V.; GUERREIRO, M. M. Distúrbio específico de linguagem: aspectos lingüísticos e neurobiológicos. In: FERREIRA, L. P.; BEFI-LOPES, D. M.; LIMONGI, S. C. O. (Eds.). Tratado de Fonoaudiologia. São Paulo: Roca, 2004.

LAI, C. S. L.; FISHER, S. E.; HURST, J. A.; VARGHAKHADEM, F.; MONACO, A. A forkhead-domain gene is mutated in a severe speech and language disorder. Nature, v. 413, n. 6885, p. 519-523, 2001.

MONTENEGRO, M. A.; GUERREIRO, M. M.; LOPESCENDES, I.; CENDES, F. Bilateral posterior parietal polymicrogyria: a mild form of congenital bilateral perisylvian syndrome? Epilepsia, v. 42, n. 7, p. 845-849, 2001.

O’BRIEN, E. K.; ZHANG, X.; NISHIMURA, C.; TOMBLIN, $B$. Association of specific language impairment to the region of 7q31. The American Journal of Human Genetics, v. 6, n. 72, p. 1536-1543, 2003.

SCHEUER, C. I.; BEFI-LOPES, D. M.; WERTZNER, H. F. Desenvolvimento da linguagem: uma introdução. In: LIMONGI, S. C. O. Fonoaudiologia: informação para a formação. Rio de Janeiro: Guanabara Koogan S. A., 2003. v. 1 .

SHAYWITZ, B. A.; SHAYWITZ, S. E.; PUGH, K. R.; FULBRIGHT, R. K.; SKUDARSKI, P.; MEND, W. E.; CONSTABLE, R. T.; MARCHIONE, K. E.; CONSTABLE, R. T.; MARCHIONE, K. E.; FLETCHER, J. M.; KLORMAN, R.; LACADIE, C.; GORE, J. C. The functional neural architecture of components of attention in language processing tasks. Neuroimage, v. 13, p. 601-612, 2001.

STEIN, L. M. TDE - Teste de desempenho escolar. São Paulo: Casa do psicólogo, 1994.

WECHSLER, D. Escala de inteligência para crianças. 3. ed. São Paulo: Casa do Psicólogo, 2002.

YAVAS, M.; HERNANDORENA, C. L. M.; LAMPRECHT, R. R. Avaliação fonológica da criança: reeducação e terapia. Porto Alegre: Artes Médicas, 1992.

Endereço para correspondência:

Ecila Paula dos Mesquita de Oliveira

R. Vitoriano dos Anjos, 471, apto. 91 - Ponte Preta - Campinas - SP - CEP: 13041-317. 